\title{
Efektivitas Penggunaan Buku Ajar Program Linier Terintegrasi Keislaman terhadap Kemampuan Komunikasi Matematis ditinjau dari Gaya Kognitif
}

\author{
Hayatun Nufus ${ }^{1}$, Rini Dian Anggraini ${ }^{2}$ \\ ${ }^{1}$ Program Studi Pendidikan Matematika, Fakultas Tarbiyah dan Keguruan, UIN Suska Riau \\ ${ }^{2}$ Program Studi Pendidikan Matematika, Fakultas Keguruan dan Ilmu Pendidikan, Universitas Riau \\ Jl. HR. Subrantas Panam Km. 15 Kecamatan Tampan - Pekanbaru \\ hayatun.nufus@uin-suska.ac.id
}

\begin{abstract}
Mathematical communication ability and cognitive style are two important things in learning mathematics. Likewise with learning programming material. These three things can be maximized through use of textbooks. Therefore, this study aims to see the effect of using Islamic linear programming textbooks on mathematical communication ablility based on cognitive style. This study used the test instrument for mathematical communication ability, cognitive style test questions, student response questionnaires to the content of Islamic material contained in textbooks, instrument validation questionnaires and questionnaire validation questionnaires for student responses. Data analysis used a two-way ANOVA test by first testing for normality and homogeneity using SPSS software. The research findings indicate that students give a positive response to the use of textbooks and the mathematical communication ability of field independent students are better than field dependent students, which is in line with the concept that field independent individuals are more analytical than field dependent individuals. The conclusions obtained in this study are: (1) there are differences in mathematical communication ability between students who learn to use Islamic integrated linear program textbooks and students who learn to use conventional learning; (2) there are differences in mathematical communication ability between students with field dependent and field independent cognitive styles; and (3) there is no interaction between the use of textbooks and cognitive style on students' mathematical communication ability.
\end{abstract}

Keywords: Textbooks, Cognitive Style, Mathematical Communication, Linear Programming

\begin{abstract}
Abstrak
Kemampuan komunikasi matematis dan gaya kognitif merupakan dua hal yang penting dalam pembelajaran matematika. Begitu juga dengan materi program linier. Ketiga hal ini bisa dimaksimalkan melalui penggunaan buku ajar. Oleh karena itu, penelitian ini dilaksanakan dengan tujuan untuk melihat pengaruh penggunaan buku ajar program linier terintegrasi keislaman terhadap kemampuan komunikasi matematis berdasarkan gaya kognitif. Instrumen yang digunakan berupa soal tes kemampuan komunikasi matematis, soal tes gaya kognitif, angket respon mahasiswa terhadap konten materi keislaman yang terdapat pada buku ajar, angket validasi instrumen soal tes dan angket validasi instrumen angket respon mahasiswa. Data dianalisis menggunakan uji anova dua arah dengan terlebih dahulu melakukan uji normalitas dan homogenitas menggunakan bantuan software SPSS. Temuan penelitian menunjukkan bahwa siswa memberikan respon yang positif terhadap penggunaan buku ajar dan kemampuan komunikasi matematis mahasiswa field independent lebih baik daripada mahasiswa field dependent, dimana hal ini sejalan dengan konsep bahwa individu field independent lebih analitik dibandingkan individu filed dependent. Kesimpulan yang diperoleh pada penelitian ini yaitu: (1) terdapat perbedaan kemampuan komunikasi matematis antara mahasiswa yang belajar menggunakan buku ajar program linier terintegrasi keislaman dengan mahasiswa yang belajar menggunakan pembelajaran konvensional; (2) terdapat perbedaan kemampuan komunikasi matematis antara mahasiswa dengan gaya kognitif field dependent dan field independent; dan (3) tidak terdapat interaksi antara penggunaan buku ajar dan gaya kognitif terhadap kemampuan komunikasi matematis mahasiswa.
\end{abstract}

Kata Kunci: Buku Ajar, Buku Ajar, Komunikasi Matematis, Program Linier

Copyright (c) 2021 Hayatun Nufus, Rini Dian Anggraini

$\triangle$ Corresponding author: Hayatun Nufus

Email Address: hayatun.nufus@uin-suska.ac.id (Jl. HR. Subrantas Panam Km. 15, Pekanbaru)

Received 14 November 2021, Accepted 24 December 2021, Published 31 December 2021

\section{PENDAHULUAN}

Komunikasi merupakan cara berbagi gagasan dan mengklarifikasi pemahaman. Proses komunikasi membantu membangun makna dan kelanggengan gagasan-gagasan serta agar gagasan- 
gagasan tersebut dapat diketahui publik. Saat para mahasiswa ditantang untuk berpikir dan bernalar tentang matematika serta untuk mengkomunikasikan hasil-hasil pemikiran mereka itu pada orang lain secara lisan atau tertulis, mereka belajar untuk menjadi jelas dan meyakinkan (Wahyudin, 2008).

Komunikasi dalam pembelajaran matematika dikenal sebagai kemampuan komunikasi matematis. Kemampuan komunikasi ini sendiri sangat penting dalam pembelajaran matematika. Hal ini senada dengan yang dikemukakan oleh Kusumah. Kusumah (Nufus \& Ariawan, 2017) mengemukakan bahwa komunikasi sangat penting dalam pembelajaran matematika karena beberapa hal, yaitu ide matematis dapat dieksploitasi dalam berbagai perspektif, mempertajam cara berpikir, mengukur peningkatan pemahaman, mengkonsolidasi dan mengorganisir pemikiran, mengkonstruksi pengetahuan matematis dan pengembangan masalah, meningkatkan penalaran, serta membentuk komunikasi.

Pembelajaran dalam setiap mata kuliah jelas memerlukan kemampuan komunikasi matematis, termasuk pada mata kuliah program linier. Program linier ini sendiri merupakan suatu mata kuliah wajib yang harus diambil oleh setiap mahasiswa pendidikan matematika. Hal ini karena materi pembelajaran pada mata kuliah ini sangat terkait erat dengan banyak bidang pada kehidupan sehari-hari, sebagaimana yang dikemukakan oleh Nufus \& Nurdin (2016) bahwa program linier banyak kegunaannya, diantaranya di bidang usaha, farmasi, kesehatan, dan transportasi.

Kemampuan komunikasi matematis mahasiswa pada mata kuliah program linier dapat dilihat pada tabel berikut ini:

Tabel 1. Deskriptif Kuantitatif Kemampuan Komunikasi Matematis Mahasiswa

\begin{tabular}{|c|c|c|c|c|c|}
\hline & T.A. 2018/2019 & \multicolumn{2}{|c|}{ T.A. 2017/2018 } & \multicolumn{2}{c|}{ T.A. 2016/2017 } \\
\cline { 2 - 6 } & Kelas B & Kelas B & Kelas C & Kelas B & Kelas C \\
\hline Rata-rata & 84,03 & 82,47 & 78,54 & 81,85 & 45 \\
\hline Maksimum & 100 & 100 & 99 & 100 & 100 \\
\hline Minimum & 40 & 25 & 35 & 25 & 10 \\
\hline
\end{tabular}

Soal yang digunakan pada tabel 1 berupa soal cerita yang menuntut mahasiswa untuk membuat model matematis dari fungsi kendala dan fungsi tujuan, menggambar grafik fungsi kendala, serta menyelesaikan persoalan dengan menggunakan tiga dari empat cara (metode grafik dan dua metode pilihan antara metode aljabar, sudut, dan simpleks). Berdasarkan tabel, memang rata-rata empat dari lima kelas baik, namun dari setiap kelas selalu ada mahasiswa yang memiliki nilai yang rendah. Artinya memang selalu ada masalah kemampuan komunikasi matematis yang terjadi pada tiap tahun ajaran.

Kemampuan komunikasi matematis mahasiswa pada mata kuliah program linier dapat dipengaruhi oleh beberapa faktor, salah satu diantaranya adalah penggunaan buku ajar pada proses pembelajaran. Pengadaan buku ajar merupakan hal yang mutlak dipersiapkan oleh dosen, sebagaimana yang dinyatakan dalam Undang-undang Republik Indonesia Nomor 12 Tahun 2012 tentang Pendidikan Tinggi (2012) Pasal 12 poin 3, yaitu dosen secara perseorangan atau berkelompok wajib menulis buku ajar atau buku teks, yang diterbitkan oleh Perguruan Tinggi dan atau publikasi ilmiah sebagai salah satu 
sumber belajar dan untuk pengembangan budaya akademik serta pembudayaan kegiatan menulis bagi civitas akademika.

Mengingat amanat Undang-Undang tersebut, maka peneliti tertarik untuk menggunakan buku ajar program linier. Pada program studi ini, telah ada buku ajar program linier yang peneliti sendiri sebagai penulis pertama didampingi seorang rekan sejawat lainnya dan buku inilah yang selama ini digunakan pada setiap kegiatan pembelajaran untuk mata kuliah program linier. Namun, buku tersebut masih bersifat umum, dengan artian belum terkait dengan nilai-nilai keislaman sedangkan buku beredar di perguruan tinggi keagamaan islam. Padahal menurut Soedjadi (Kurniati, 2015), nilai moral dan akhlak seseorang terbentuk dari hasil internalisasi berbagai kebajikan, diyakini dan digunakan sebagai landasan untuk cara pandang, berpikir, bersikap, dan bertindak. Selain itu, buku tersebut juga masih menampilkan soal-soal yang masih bersifat umum, belum spesifik untuk soal yang memfasilitasi kemampuan komunikasi matematis mahasiswa. Oleh karena itu, perlu adanya integrasi ilmu keislaman dengan matematika.

Integrasi yang sinergis antara agama dan ilmu pengetahuan secara konsisten akan menghasilkan sumber daya yang handal dalam mengaplikasikan ilmu yang dimiliki dengan diperkuat oleh spiritualitas yang kokoh dalam menghadapi kehidupan (Turmudi, 2006). Spiritulitas yang dimaksud disini jelas adalah terkait spiritualitas keislaman. Oleh karena itu, konsep integrasi keilmuan juga berangkat dari doktrin keesaan Allah, yang tidak sekedar berbicara kategori etika. Ia adalah suatu kategori kognitif yang berhubungan dengan pengetahuan (Akbarizan, 2014). Buku ajar terintegrasi keislaman ini diharapkan dapat mendukung dalam menghasilkan mahasiswa sebagai calon guru matematika yang memiliki spiritualitas keislaman yang baik.

Selain penggunaan buku ajar, ada faktor lain yang juga turut mempengaruhi kemampuan komunikasi matematis, yaitu gaya kognitif. Menurut Sternberg dan Elena (Ariawan \& Nufus, 2017), gaya kognitif merupakan jembatan antara kecerdasan dan kepribadian. Selanjutnya, Woolfolk (1993) menyatakan gaya kognitif adalah suatu cara yang berbeda untuk melihat, mengenal, dan mengorganisasi informasi. Gaya kogninif seseorang dapat menunjukkan variasi individu dalam hal perhatian, penerimaan informasi, mengingat, dan berpikir yang muncul atau berbeda di antara kognisi dan kepribadian.

Variasi gaya kognitif ini terdiri atas dua kategori, yaitu gaya kognitif field dependent dan field independent. O'Brien, Butler, \& Bernold (2001) menyatakan bahwa individu field dependent memiliki ciri-ciri: lebih global dan holistik dalam pengolahan persepsi dan informasi sehingga sering disebut sebagai "global thinkers" serta cenderung menerima informasi seperti yang disajikan atau dijumpai dan mengandalkan sebagian besar pada cara menghafal. Individu field independent memiliki ciri-ciri: memiliki analisis yang lebih tinggi dalam penerimaan dan pemprosesan informasi, sehingga sering disebut sebagai "analytical thinkers" serta cenderung untuk mengorganisasikan informasi menjadi unitunit yang dapat dikelola dan memiliki kapasitas yang lebih besar untuk penyimpanan informasi. Orang 
atau indvidu yang tergolong ke dalam Field Independent terbiasa menggunakan teknik pemecahan masalah, organisasi, analisis dan penataan ketika telibat dalam situasi belajar dan bekerja.

Berdasarkan uraian penjelasan di atas, maka tujuan pada penelitian ini yaitu untuk menguji pengaruh penggunaan buku ajar program linier terintegrasi keislaman terhadap kemampuan komunikasi matematis mahasiswa ditinjau berdasarkan gaya kognitif. Tujuan ini dijabarkan dalam tiga hal, yaitu (1) untuk melihat ada atau tidaknya perbedaan kemampuan komunikasi matematis antara mahasiswa yang belajar menggunakan buku ajar program linier terintegrasi keislaman dengan mahasiswa yang belajar menggunakan pembelajaran konvensional; (2) untuk melihat ada atau tidaknya perbedaan kemampuan komunikasi matematis antara mahasiswa dengan gaya kognitif field dependent dan field independent; dan (3) untuk melihat ada atau tidaknya interaksi penggunaan buku ajar dan gaya kognitif terhadap kemampuan komunikasi matemati mahasiswa.

\section{METODE}

Penelitian ini menggunakan jenis penelitian kuantitatif. Penelitian dilaksanakan dengan berpedoman pada desain the nonequivalent posttest only kontrol group design sebagaimana yang digambarkan oleh (Lestari \& Yudhanegara, 2017). Kegiatan penelitian dilakukan pada semester genap tahun ajaran 2020/2021 di salah satu Perguruan Tinggi negeri yang ada di Pekanbaru, Riau.

Sesuai dengan sajian mata kuliah pada universitas tersebur, maka populasi pada penelitian ini adalah mahasiswa semester empat yang ada di program studi pendidikan matematika. Dengan menggunakan simple random sampling, terpilihlah dua dari 5 kelas untuk dijadikan sampel penelitian. Mahasiswa kelas IV A sebagai kelompok eksperimen (kelas eksperimen) dan kelas IV B sebagai kelompok kontrol (kelas kontrol). Kedua kelas melaksanakan kegiatan pembelajaran secara online menggunakan aplikasi google classroom dan google meet. Kelas eksperimen menggunakan buku ajar program linier terintegrasi keislaman dan kelas kontrol menggunakan buku ajar yang biasa digunakan pada mata kuliah program linier pada tahun-tahun sebelumnya.

Intrumen penelitian terdiri atas perangkat pembelajaran dan instrumen pengumpulan data. Perangkat pembelajaran yang dimaksud pada penelitian ini terdiri atas Rencana Pembelajaran Semester (RPS) dan buku ajar program linier terintegrasi keislaman. RPS yang dimaksud pada penelitian ini mengiikut pada format yang berlaku di universitas.

Buku ajar program linier yang dimaksud pada penelitian ini memuat cover, judul bab, tujuan pembelajaran, konsep materi, judul subbab, sajian materi, contoh soal, rangkuman, dan latihan - latihan. Adapun materi yang dibahas pada buku ajar ini terdiri atas lima bab, yaitu: pengantar dasar program linier, metode grafik, metode aljabar, metode sudut, dan metode simpleks. Semuanya mulai dari cover hingga daftar pustaka berjumlah 81 halaman dengan ukuran kertas A5. Pada buku ajar ini juga terdapat kata-kata mutiara yang bersifat motivasi yang berasal dari hadits Rasulullah Saw. Materi, contoh soal, dan soal disetting dalam bentuk narasi Islami terkait sirah dan fiqih Islam. 
Buku ajar ini terlebih dahulu sudah divalidasi dan diuji coba. Hasil validasi menunjukkan bahwa buku ajar berada pada kategori sangat valid dengan persentase kevalidan sebesar 92,5\%. Hasil ujicoba kepraktisan buku ajar menunjukkan bahwa buku ajar ini sangat praktis untuk digunakan dengan persentase kepraktisan sebesar $85,5 \%$. Berikut ini adalah contoh konten keislaman yang terdapat pada buku ajar.
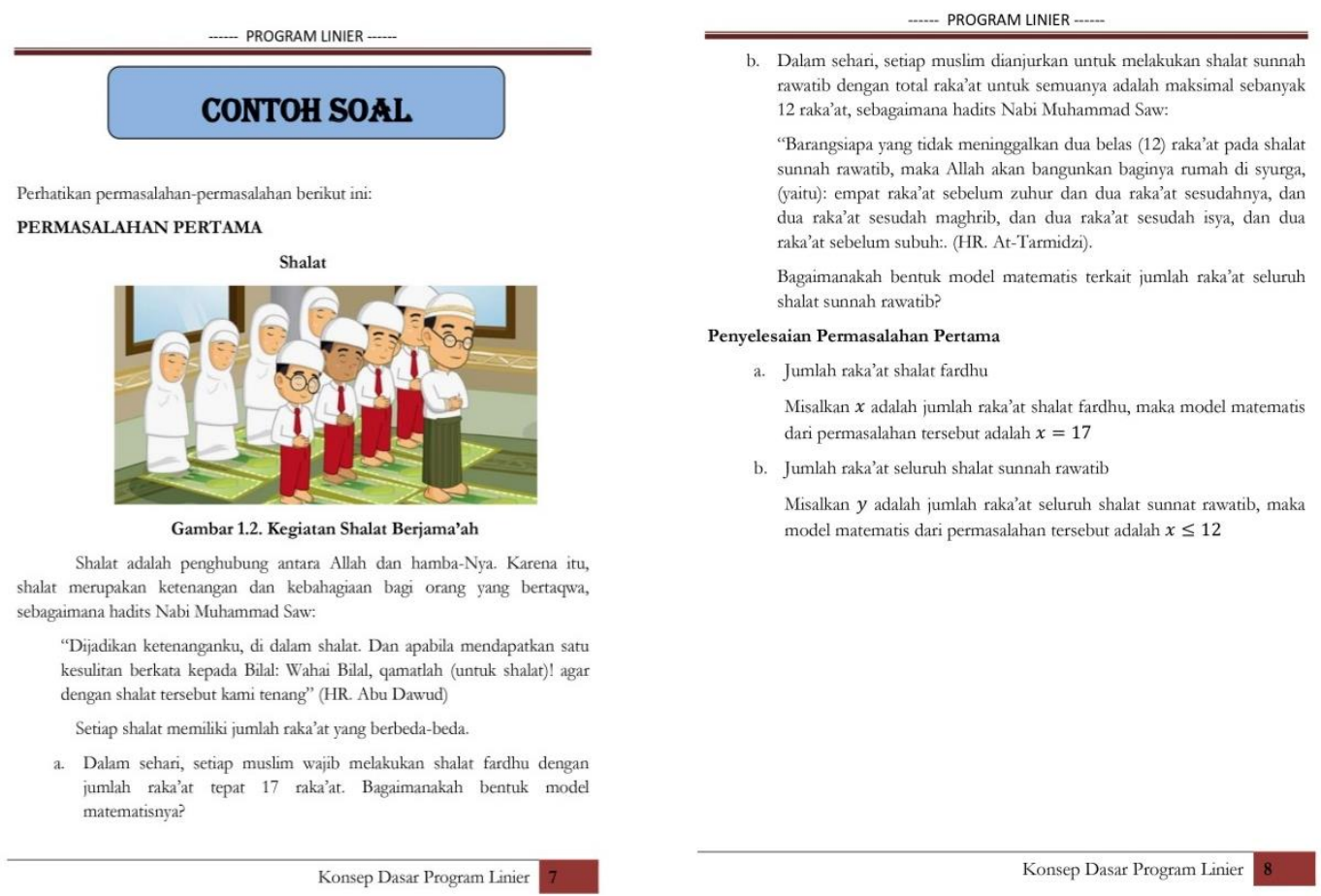

Gambar 1. Contoh Konten Keislaman pada Buku Ajar

Pengumpulan data dilakukan dengan menggunakan teknik tes dan non tes. Teknik tes dilakukan untuk mengumpulkan data terkait kemampuan komunikasi matematis dan jenis gaya kognitif mahasiswa. Teknik non tes digunakan untuk mengumpulkan data terkait respon mahasiswa terhadap konten materi keislaman yang terdapat pada buku ajar dan terkait validasi atas instrumen penelitian. Oleh karena itu, instrumen yang digunakan pada penelitian ini terdiri atas lima, dua berupa soal dan tiga berupa angket.

Instrumen pengumpulan data yang pertama yaitu soal tes kemampuan komunikasi matematis. Berdasarkan indikator yang dikemukan oleh Lestari \& Yudhanegara (2017), Hendriana, Rohaeti, \& Sumarmo (2017), serta Sumarmo (2013), soal disusun dengan berpedoman pada tiga indikator berikut: (1) menjelaskan ide, situasi, dan relasi matematika secara tertulis dengan menggunakan gambar, grafik, maupun secara aljabar; (2) membaca representasi matematika tertulis dengan pemahaman dan menuliskannya dan (3) menyatakan peristiwa sehari-hari ke dalam model matematis dan menyelesaikannya. Rincian sebaran indikator kemampuan komunikasi matematis dapat dilihat pada tabel 2 berikut.

Tabel 2. Rincian Sebaran Indikator Kemampuan Komunikasi Matematis dalam Butir Soal 


\begin{tabular}{|c|c|}
\hline Indikator Kemampuan Komunikasi Matematis & $\begin{array}{c}\text { Nomor } \\
\text { Soal }\end{array}$ \\
\hline $\begin{array}{l}\text { Menjelaskan ide, situasi, dan relasi matematika secara tertulis dengan } \\
\text { menggunakan gambar, grafik, maupun secara aljabar. }\end{array}$ & $1 \mathrm{a}$ \\
\hline $\begin{array}{c}\text { Membaca representasi matematika tertulis dengan pemahaman dan } \\
\text { menuliskannya. }\end{array}$ & 3 \\
\hline $\begin{array}{c}\text { Menjelaskan ide, situasi, dan relasi matematika secara tertulis dengan } \\
\text { menggunakan gambar, grafik, maupun secara aljabar. }\end{array}$ & $2 \mathrm{a}$ \\
\hline $\begin{array}{l}\text { Menyatakan peristiwa sehari-hari ke dalam model matematis dan } \\
\text { menyelesaikannya. }\end{array}$ & $2 b$ \\
\hline $\begin{array}{c}\text { Menyatakan peristiwa sehari-hari ke dalam model matematis dan } \\
\text { menyelesaikannya. }\end{array}$ & $1 \mathrm{~b}$ \\
\hline
\end{tabular}

Sebelum digunakan, ketiga soal tes ini divalidasi dan diuji coba terlebih dahulu. Hasil validasi oleh dua orang validator menunjukkan bahwa ketiga soal tes masuk pada kategori sangat valid, dengan masing-masing nilai validitasnya yaitu $96 \%, 96 \%$, dan 98\%, dengan rincian sebagai berikut.

Tabel 3. Rincian Penilaian Validasi Soal Tes Kemampuan Komunikasi Matematis

\begin{tabular}{|c|c|c|c|c|c|c|}
\hline \multirow{2}{*}{\begin{tabular}{c} 
Aspek yang diamati \\
\cline { 2 - 7 }
\end{tabular}} & Soal 1 & Soal 2 & Soal 3 & Soal 1 & Soal 2 & $\begin{array}{c}\text { Soal } \\
\mathbf{3}\end{array}$ \\
\hline $\begin{array}{c}\text { Kesesuaian soal dengan tujuan } \\
\text { pembelajaran }\end{array}$ & 5 & 5 & 5 & 5 & 5 & 5 \\
\hline $\begin{array}{c}\text { Kesesuaian soal dengan indikator } \\
\text { kemampuan komunikasi matematis }\end{array}$ & 5 & 5 & 5 & 5 & 5 & 4 \\
\hline Kesesuaian soal dengan indikator soal & 5 & 5 & 5 & 5 & 5 & 5 \\
\hline Kejelasan maksud soal & 4 & 5 & 5 & 5 & 4 & 5 \\
\hline Kemungkinan soal dapat terselesaikan & 4 & 5 & 5 & 5 & 4 & 5 \\
\hline Jumlah & 23 & 25 & 25 & 25 & 23 & 24 \\
\hline Rata-rata & 4,6 & 5 & 5 & 5 & 4,6 & 4,8 \\
\hline Persentase kevalidan (\%) & 92 & 100 & 100 & 100 & 92 & 96 \\
\hline
\end{tabular}

Adapun hasil uji coba soal tes dapat dilihat pada tabel 4 berikut.

Tabel 4. Rekapitulasi Skor Uji Coba Soal Tes Kemampuan Komunikasi Matematis

\begin{tabular}{|c|c|c|c|c|c|c|}
\hline \multirow{2}{*}{$\begin{array}{c}\text { Nomor } \\
\text { Soal }\end{array}$} & \multicolumn{2}{|c|}{ Validitas } & \multicolumn{2}{c|}{ Daya Pembeda } & \multicolumn{2}{c|}{ Tingkat Kesukaran } \\
\cline { 2 - 7 } & Nilai & Kategori & Nilai & Kategori & Nilai & Kategori \\
\hline 1 & 0,744 & Tinggi & 0,4563 & Baik & 0,5281 & Sedang \\
\hline 2 & 0,750 & Tinggi & 0,4625 & Baik & 0,7188 & Mudah \\
\hline 3 & 0,689 & Tinggi & 0,30 & Cukup & 0,8125 & Mudah \\
\hline
\end{tabular}

Catatan: Reliabilitas sebesar 0,57 (Cukup)

Berdasarkan tabel di atas, maka instrumen soal tes kemampuan komunikasi matematis siap untuk digunakan. Adapun salah satu bunyi soal tes tersebut adalah: 


\title{
SOAL KEDUA
}

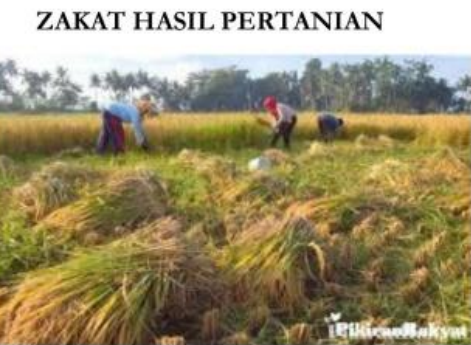

Gambar 1. Kegiatan Memanen Padi

\begin{abstract}
Zakat memiliki posisi yang sangat penting, strategis dan menentukan, baik dari sisi ajaran maupun dari sisi pembangunan kesejahteraan umat. Salah satu yang dikenai zakat adalah hasil pertanian, sebagaimana firman Allah SWT:

"Hai orang-orang yang beriman, nafkahkanlah (di jalan Allah) sebagian dari hasil usahamu yang baik-baik dan sebagian dari apa yang Kami keluarkan dari bumi untuk kamu" (QS. Al-Baqarah: 267).

Namun, tidak semua hasil pertanian terkena zakat. Akan tetapi, yang dikenai zakat adalah jenis-jenis tertentu dengan kadar tertentu. Padi adalah salah satu jenis hasil pertanian yang dikenai zakat, dimana penunaian zakatnya tidak menunggu baul, melainkan setiap kali panen ada zakatnya, dengan kriteria:

a. Jika tanaman diari dengan air hujan atau dengan air sungai tanpa ada biaya yang dikeluarkan atau bahkan tanaman tersebut tidak membutuhkan air, dikenai zakat sebesar $10 \%$.

b. Jika tanaman diairi dengan air yang memerlukan biaya untuk pengairan misalnya membutuhkan pompa untuk menarik air dari sumbernya, maka dikenai zakat sebesar $5 \%$.

c. Hitungan $10 \%$ dan $5 \%$ adalah dari hasil panen dan tidak dikurangi dengan biaya untuk menggarap lahan dan biaya operasional lainnya.
\end{abstract}

Perhatikanlah permasalahan berikut ini

Pak Amirullah terkenal sebagai petani kaya yang dermawan dan shaleh di kabupatennya. Diantara sekian banyak jenis usaha pertaniannya, Pak Amirullah memiliki paling banyak 70 petak sawah yang diari air hujan dan 84 petak sawah yang memerlukan biaya pengairan yang tersebar di dua desa. 2 petak sawah yang diari air hujan tanpa mengeluarkan biaya pengairan dan 4 petak sawah yang diairi dengan air yang memerlukan biaya pengairan berada di desa A. Sementara di desa B, beliau memiliki 5 petak sawah yang diari air hujan tanpa mengeluarkan biaya pengairan dan 3 petak sawah yang diairi dengan air yang memerlukan biaya pengairan. Semua sawah-sawah tersebut menghasilkan padi yang berkualitas. Setiap petak sawah menghasilkan beras siap jual dengan harga jual 10.000 per kilogram sebanyak 2,5 ton untuk sawah yang diari air hujan dan 5 ton untuk sawah yang memerlukan biaya pengairan. Sebagai wujud rasa syukur dan ketaatan atas perintah Allah, beliau senantiasa mengeluarkan zakat dari hasil panen yang dilakukan setiap kali selesai panen. Jika pak Amirullah menginginkan penghasilan yang maksimal dari sawah-sawahnya, maka:

a. Berapakah petak sawah yang diari air hujan dan berapakah petak sawah yang memerlukan biaya pengairan yang harus beliau kelola secara maksimal? Selesaikanlah soal dengan menggunakan metode aljabar dan sudut.

b. Dari jawaban a, berapakah total zakat yang harus beliau keluarkan untuk sekali panen?

\section{Gambar 2. Salah Satu Soal Tes Kemampuan Komunikasi Matematis}

Instrumen yang kedua, soal tes gaya kognitif. soal tes ini berupa soal Group Embedded Figures Test (GEFT) yang dikembangkan oleh Witkin. Soal ini mengarahkan individu untuk mencari serangkaian bentuk sederhana dalam bentuk yang lebih kompleks dan lebih besar. Soal GEFT pada penelitian ini menggunakan soal GEFT yang telah baku digunakan di Amerika dengan tingkat reliabilitas sangat tinggi, sebesar 0,84 (Ulya, 2015).

Soal tes GEFT terdiri atas tiga bagian. Bagian pertama berfungsi sebagai latihan yang sifatnya lebih mudah, sehingga ketujuh soal pada bagian pertama ini tidak diperhitungkan dalam pengkategorian jenis gaya keognitif. Perhitungan skor GEFT didasarkan pada skor jawaban atas bagian kedua dan ketiga yang masing-masingnya terdiri atas 9 soal. Skor 1 untuk jawaban benar dan skor 0 untuk jawaban 
salah. Individu dikatakan memiliki gaya kognitif field dependent jika memperoleh skor 0-11 dan memiliki gaya kognitif field independent jika memperoleh skor 12-18. Instrumen yang ketiga yaitu angket respon mahasiswa terhadap konten materi keislaman yang terdapat pada buku ajar. Angket ini disusun meliputi enam indikator dengan jumlah pernyataan sebanyak 20 pernyataan. Lebih lengkapnya dapat dilihat pada tabel 5 berikut.

Tabel 5. Kisi-kisi Angket Respon Mahasiswa terhadap Konten Materi Keislaman

\begin{tabular}{|c|c|c|c|c|}
\hline \multirow{2}{*}{ No. } & \multirow{2}{*}{ Indikator } & \multicolumn{2}{|c|}{ Pernyataan } & \multirow{2}{*}{$\begin{array}{c}\text { Jumla } \\
\text { h }\end{array}$} \\
\hline & & Positif & Negatif & \\
\hline 1 & $\begin{array}{l}\text { Kesesuaian kata-kata mutiara yang digunakan untuk } \\
\text { menstimulus minat membaca mahasiswa. }\end{array}$ & 5 & 9 & 2 \\
\hline 2 & $\begin{array}{l}\text { Kemenarikan penyajian konten materi keislaman pada } \\
\text { buku ajar dalam meningkatkan pemahaman keislaman } \\
\text { mahasiswa. }\end{array}$ & $\begin{array}{l}2,10,12,1 \\
9\end{array}$ & $\begin{array}{c}4,7,15,1 \\
7\end{array}$ & 8 \\
\hline 3 & $\begin{array}{l}\text { Kesesuaian konten materi keislaman yang disajikan pada } \\
\text { buku ajar dengan tujuan pembelajaran. }\end{array}$ & 13 & 3 & 2 \\
\hline 4 & $\begin{array}{l}\text { Kesesuaian contoh soal dengan kebenaran konten materi } \\
\text { keislaman yang diangkat. }\end{array}$ & 20 & 16 & 2 \\
\hline 5 & $\begin{array}{l}\text { Kesesuaian soal latihan dengan kebenaran konten materi } \\
\text { keislaman yang diangkat. }\end{array}$ & 14 & 6 & 2 \\
\hline 6 & $\begin{array}{l}\text { Keberadaan konten keislaman pada buku ajar dalam } \\
\text { membawa perubahan kepada diri mahasiswa. }\end{array}$ & 1,18 & 11,8 & 4 \\
\hline & JUMLAH & 10 & 10 & 20 \\
\hline
\end{tabular}

Angket respon mahasiswa ini disusun dengan menggunakan skala Likert. Selanjutnya, data angket dianalisis menggunakan statistik deskriptif berupa rata-rata untuk kemudian persentasenya diinterpretasikan sesuai dengan kategori tingkatan yang bersesuaian (Riduwan \& Sunarto, 2013). Berdasarkan hasil validasi, diperoleh bahwa angket repon mahasiswa dengan dua puluh pernyataan ini sangat valid untuk digunakan dengan persentase kevalidan sebesar 83,335\%.

Instrumen yang keempat yaitu lembar validasi instrumen penelitian. Instrumen ini disusun untuk memperoleh data terkait besaran validasi instrumen soal tes kemampuan komunikasi matematis dan instrumen angket respon mahasiswa. Perbaikan yang dilakukan atas saran validator dan patokan nilai persentase validasi beserta interpretasinya menjadikan instrumen yang disusun layak untuk digunakan.

Data pada penelitian ini dianalisis melalui analisis statistik inferensial menggunakan uji anova dua arah. Uji anova dua arah ini digunakan karena penelitian ini bertujuan untuk melihat pengaruh dengan melibatkan tiga variabel dengan 1 variabel terikat (kemampuan komunikasi matematis) dan 2 variabel bebas (penggunaan buku ajar program linier dan gaya kognitif). Sebelum dilakukan uji anova dua arah, terlebih dahulu dilakukan uji normalitas dan homogenitas. Semua uji statistik ini dilakukan dengan bantuan software SPSS. 


\section{HASIL DAN DISKUSI}

\section{Data Gaya Kognitif Mahasiswa}

Pada penelitian ini, mahasiswa diklasifikasikan ke dalam 2 jenis kelompok. Pertama, pengklasifikasian berdasarkan kegiatan pembelajaran, mahasiswa di kelompokkan atas kelas eksperimen dan kelas kontrol. Kelas eksperimen melaksanakan kegiatan pembelajaran dengan menggunakan buku ajar program linier terintegrasi keislaman.

Kedua, pengklasifikasian berdasarkan kategori gaya koginitif. Mahasiswa dikelompokkan menjadi dua kategori, yaitu dengan gaya kognitif field dependent dan gaya kognitif field independent. Pengklasifikasian ini didasarkan pada hasil uji tes gaya kognitif menggunakan instrumen soal GEFT.

Pelaksanaan kegiatan tes GEFT ini dilakukan sebelum dilaksanakannya pembelajaran di kelas eksperimen dan kelas kontrol. Pada kedua kelas ini, tes GEFT dilakukan pada hari senin tanggal 08 Maret 2021. Soal GEFT diposting pada menu tugas di google classroom masing-masing kelas dan jawaban diupload dalam bentuk file PDF.

Soal tes GEFT ini terdiri atas tiga bagian. Namun, untuk penilaian hanya melibatkan skor siswa atas jawaban pada bagian kedua dan ketiga. Bagian pertama tidak dijadikan pertimbangan, karena memang soal untuk jawaban pertama sangatlah mudah. Dan, berdasarkan hasil penilaian, semua siswa mendapatkan nilai penuh, yaitu 7 . Tidak ada satupun mahasiswa yang tidak mendapat nilai sempurna untuk soal bagian pertama ini.

Tabel 6. Sebaran Jumlah Mahasiswa untuk Masing-masing Kategori

\begin{tabular}{|c|c|c|c|}
\hline & Field Dependent & Field Independent & Keseluruhan \\
\hline Eksperimen & 9 orang & 17 orang & 26 orang \\
\hline Kontrol & 3 orang & 23 orang & 26 orang \\
\hline Keseluruhan & 12 orang & 40 orang & 52 orang \\
\hline
\end{tabular}

Pada tabel 6, terlihat bahwa mahasiswa dengan kategori field independent lebih banyak daripada mahasiswa dengan kategori field dependent. Artinya, sebagian besar mahasiswa memiliki analisis yang tinggi dalam penerimaan dan pemrosesan informasi, cenderung membagi informasi ke dalam hal-hal yang detail serta terbiasa menggunakan teknik pemecahan masalah dalam bekerja. Lebih rinci, berikut adalah rincian mahasiswa berdasarkan kategori gaya kognitif untuk masing-masing kelas eksperimen dan kelas kontrolnya.

\section{Data Respon Mahasiswa Terkait Konten Materi Keislaman pada Buku Ajar}

Setelah pelaksanaan pembelajaran menggunakan buku ajar program linier terintegrasi keislaman, maka peneliti menyebarkan angket respon mahasiswa terkait konten materi keislaman yang terdapat pada buku ajar. Hal ini dilakukan agar peneliti memperoleh informasi terkait pengaruh praktis yang diperoleh mahasiswa setelah menggunakan buku ajar. Adapun rincian data respon tersebut dapat dilihat pada tabel 8 berikut: 
Tabel 8. Sebaran Skor Rata-rata Respon Mahasiswa terhadap Konten Materi Keislaman yang Terdapat pada Buku Ajar berdasarkan Indikator

\begin{tabular}{|c|l|c|c|}
\hline NO & \multicolumn{1}{|c|}{ INDIKATOR } & $\begin{array}{c}\text { RATA- } \\
\text { RATA }\end{array}$ & $\begin{array}{c}\text { PERSENTAS } \\
\text { E }\end{array}$ \\
\hline 1 & $\begin{array}{l}\text { Kesesuaian kata-kata mutiara yang digunakan untuk } \\
\text { menstimulus minat membaca mahasiswa. }\end{array}$ & 3,94 & 78,85 \\
\hline 2 & $\begin{array}{l}\text { Kemenarikan penyajian konten materi keislaman pada } \\
\text { buku ajar dalam meningkatkan pemahaman keislaman } \\
\text { mahasiswa. }\end{array}$ & 3,96 & 79,23 \\
\hline 3 & $\begin{array}{l}\text { Kesesuaian konten materi keislaman yang disajikan pada } \\
\text { buku ajar dengan tujuan pembelajaran. }\end{array}$ & 3,96 & 79,23 \\
\hline 4 & $\begin{array}{l}\text { Kesesuaian contoh soal dengan kebenaran konten materi } \\
\text { keislaman yang diangkat. }\end{array}$ & 3,98 & 79,62 \\
\hline 5 & $\begin{array}{l}\text { Kesesuaian soal latihan dengan kebenaran konten materi } \\
\text { keislaman yang diangkat. }\end{array}$ & 4,04 & 80,77 \\
\hline 6 & $\begin{array}{l}\text { Keberadaan konten keislaman pada buku ajar dalam } \\
\text { membawa perubahan kepada diri mahasiswa. }\end{array}$ & 4,02 & 80,38 \\
\hline \multicolumn{2}{|c|}{ Rata-rata keseluruhan } & $\mathbf{3 , 9 5}$ \\
\hline \multicolumn{2}{|c|}{ Persentase keseluruhan } & $\mathbf{7 9 , 0 8}$ \\
\hline
\end{tabular}

Berdasarkan data pada tabel 8, terlihat jelas bahwa kelima aspek indikator memiliki rentang persentase yang bisa dikatakan seragam, yaitu antara rentang $78 \%$ hingga $80 \%$. Jika dikonversikan pada pembagian lima kategori (sangat tinggi, tinggi, cukup, rendah, dan sangat rendah), maka keenam aspek ini berada pada kategori yang sama, yaitu kategori tinggi (Riduwan \& Sunarto, 2013). Hal ini menunjukkan bahwa buku ajar yang digunakan mendapat perhatian dan respon yang baik dari mahasiswa.

Selanjutnya, persentase terendah respon yang diberikan mahasiswa adalah terkait aspek "Kesesuaian kata-kata mutiara yang digunakan untuk menstimulus minat membaca mahasiswa". Artinya, kata-kata mutiara yang digunakan belum memiliki daya tarik yang sangat kuat untuk membuat mahasiswa membaca buku ajar ini. Sementara persentase respon tertinggi adalah terkait aspek "Kesesuaian soal latihan dengan kebenaran konten materi keislaman yang diangkat". Artinya, mahasiswa memiliki kecenderungan untuk mempercayai apapun konten keislaman yang disajikan pada buku ajar ini.

\section{Kegiatan Pembelajaran pada Kelas Eksperimen dan Kelas Kontrol}

Pada kelas kontrol, kegiatan pembelajaran menggunakan buku ajar yang selama ini telah digunakan sejak beberapa tahun sebelumnya (dimana penulisnya juga peneliti sendiri) dan juga peneliti upload softfile PDF buku tersebut ke menu materi di google classroom. Pada kelas eksperimen, kegiatan pembelajaran menggunakan buku ajar program linier terintegrasi keislaman yang telah peneliti susun dan diupload dalam bentuk file PDF pada menu materi di goggle classroomnya. Selain itu, juga ditambah soft file buku ajar yang sama dengan yang digunakan di kelas kontrol. Namun, pada pelaksanaan kegiatan pembelajaran tetap hanya fokus menggunakan buku ajar terintegrasi keislaman. 
Pada kedua kelas, baik kelas eksperimen maupun kelas kontrol, sistematika urutan pelaksanaan kegiatan pembelajaran sama. Pada pertemuan pertama dan kedua, urutan kegiatan yaitu: (1) Dosen membuka kelas menggunakan aplikasi google classroom; (2) Dosen meminta mahasiswa untuk mengisi pertanyaan absensi kehadiran yang telah diposting di google classroom; (3) Dosen meminta mahasiswa yang telah mengisi pertanyaan absensi kehadiran untuk bergabung di link google meet yang ada di kelas google classroom masing-masing; (4) Dosen menjelaskan materi pembelajaran dengan melakukan presentasi buku ajar dengan penjelasan yang lebih rinci dan detail sambil mahasiswa juga membuka buku ajar yang sama, lalu dilanjutkan dengan diskusi kelas menggunakan aplikasi google meet; (5) Jika terdapat pertanyaan yang tidak bisa dijelaskan secara langsung melalui google meet karena membutuhkan penjelasan tertulis, maka mahasiswa dipersilakan menuliskan pertanyaan tersebut di postingan forum google classroom dan dosen menjawab pertanyaan di komentar postingan pertanyaan yang bersesuaian atau membuat postingan baru jika kejelasan jawaban membutuhkan lampiran berupa foto catatan jawaban; (6) Jika pertanyaan atau diskusi sudah tidak ada lagi dan waktu telah sampai pada akhir jadwal, dosen mengupload soal tugas yang harus dikerjakan dan diupload jawabannya sesuai dengan batas waktu yang telah ditentukan pada postingan tugas yang bersesuaian; dan (7) Dosen menutup kegiatan pembelajaran.

Pada pertemuan ketiga, keempat, dan kelima, kegiatan pembelajaran tidak lagi menggunakan google meet, melainkan full menggunakan google classroom. Hal ini karena berdasarkan usulan mahasiswa yang menyatakan bahwa mereka banyak tertinggal penjelasan materi ketika menggunakan google meet, dengan kondisi sebagian besar mereka terkendala dengan jaringan internet dan melalui diskusi serta kesepakatan bersama maka diputuskanlah hanya menggunakan google classroom saja.

Adapun rincian teknis kegiatan pembelajaran untuk ketiga pertemuan ini yaitu: (1) Dosen membuka kelas menggunakan aplikasi google classroom; (2) Dosen meminta mahasiswa untuk mengisi pertanyaan absensi kehadiran yang telah diposting di google classroom; (3) Dosen meminta mahasiswa yang telah mengisi pertanyaan absensi kehadiran untuk membaca materi pembelajaran yang telah diposting (berupa softfile buku ajar) sesuai dengan jangka waktu yang ditentukan; (4) Jika terdapat pertanyaan atau hal yang ingin didiskusikan, mahasiswa menuliskan pertanyaan tersebut di postingan forum google classroom dan dosen menjawab pertanyaan di komentar postingan pertanyaan yang bersesuaian atau membuat postingan baru jika kejelasan jawaban membutuhkan lampiran berupa foto catatan jawaban; (6) Jika pertanyaan atau diskusi sudah tidak ada lagi dan waktu telah sampai pada akhir jadwal, dosen mengupload soal tugas yang harus dikerjakan dan diupload jawabannya sesuai dengan batas waktu yang telah ditentukan pada postingan tugas yang bersesuaian; dan (7) Dosen menutup kegiatan pembelajaran.

Pada pertemuan keenam, kegiatan pembelajaran adalah pelaksanaan tes. Kegiatan tes ini terkait soal tes kemampuan komunikasi matematis yang telah direvisi berdasarkan hasil validasi oleh pakar dan hasil uji coba. Pelaksanaan kegiatan tes ini dilakukan secara bersamaan untuk kedua kelas (kelas eksperimen dan kelas kontrol) menggunakan aplikasi google classroom. Adapun teknis pelaksanaannya 
adalah: (1) Dosen mengupolad soal pertama tes kemampuan komunikasi matematis di menu tugas pada google classroom beberapa menit sebelum jadwal perkuliahan; (2) Dosen membuka kelas melalui postingan di google classroom; (3) Dosen meminta mahasiswa mengerjakan soal pertama dengan jangka waktu 35 menit (jawaban sudah diupload dalam jangka waktu 35 menit ini, dalam bentuk file PDF); (4) Lima menit sebelum akhir batas waktu jawaban soal pertama diupload, dosen mengupload soal kedua; (5) Dosen meminta mahasiswa mengerjakan soal kedua dengan jangka waktu 35 menit (jawaban sudah diupload dalam jangka waktu 35 menit ini, dalam bentuk file PDF); (6) Lima menit sebelum akhir batas waktu jawaban soal kedua diupload, dosen mengupload soal ketiga; (7) Dosen meminta mahasiswa mengerjakan soal ketiga dengan jangka waktu 30 menit (jawaban sudah diupload dalam jangka waktu 30 menit ini, dalam bentuk file PDF); (8) Dosen menutup kegiatan pembelajaran.

\section{Data Kemampuan Komunikasi Matematis Mahasiswa}

Data terkait kemampuan komunikasi matematis mahasiswa diperoleh berdasarkan jawaban mahasiswa atas soal tes kemampuan komunikasi matematis yang diujikan. Adapun rekapitulasi data skor kemampuan komunikasi matematis tersebut dapat dilihat pada tabel 9 berikut:

Tabel 9. Rata-rata Skor Kemampuan Komunikasi Matematis Mahasiswa

\begin{tabular}{|c|c|c|c|}
\hline & Field Dependent & Field Independent & Keseluruhan \\
\hline Eksperimen & 10,67 & 13,29 & 12,38 \\
\hline Kontrol & 9,67 & 11,48 & 11,27 \\
\hline Keseluruhan & 10,42 & 12,25 & 11,83 \\
\hline
\end{tabular}

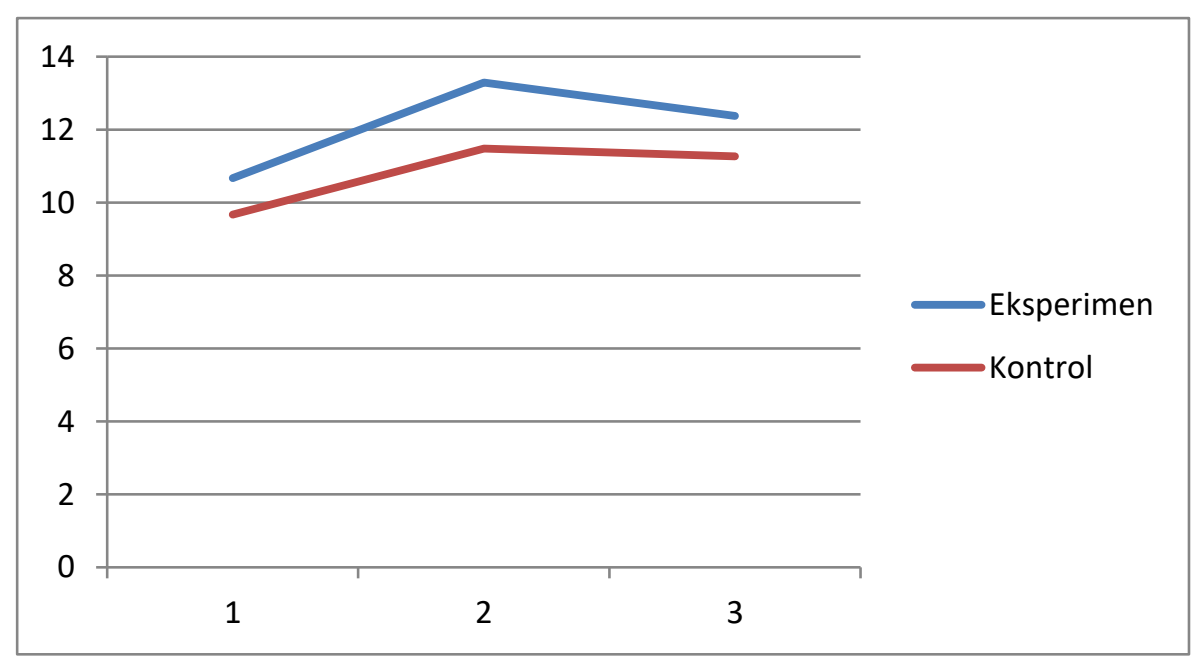

Gambar 3. Grafik Skor Kemampuan Komunikasi Matematis Mahasiswa dilihat berdasarkan Penggunaan Buku Ajar

Pada gambar 3, tampak bahwa kemampuan komunikasi matematis mahasiswa kelas eksperimen (kelas yang melaksanakan kegiatan pembelajaran menggunakan buku ajar program linier terintegrasi keislaman) lebih baik dibandingkan kelas kontrol (kelas yang melaksanakan kegiatan pembelajaran sebagaimana biasanya, menggunakan buku ajar yang pada tahun-tahun sebelumnya juga digunakan). Selain itu, jika dilihat dari sudut pandang gaya kognitif, kemampuan komunikasi matematis mahasiswa dengan gaya kognitif field independent lebih baik dibandingkan field dependent. 
Selanjutnya, kehomogenan (keseragaman) kemampuan komunikasi matematis mahasiswa antar kelas dan antar kategori gaya kognitif dapat dilihat dengan memperhatikan nilai simpangan baku pada tabel 10 berikut:

Tabel 10. Simpangan Baku Skor Kemampuan Komunikasi Matematis Mahasiswa

\begin{tabular}{|c|c|c|c|}
\hline & Field Dependent & Field Independent & Keseluruhan \\
\hline Eksperimen & 2,784 & 3,949 & 3,753 \\
\hline Kontrol & 2,082 & 3,013 & 2,947 \\
\hline Keseluruhan & 2,575 & 3,514 & 3,388 \\
\hline
\end{tabular}

Pada tabel 10, tampak bahwa simpangan baku skor kemampuan komunikasi matematis mahasiswa dengan gaya kognitif field independent lebih tinggi dibandingkan field dependent. Hal ini menunjukkan bahwa kemampuan komunikasi matematis mahasiswa field dependent lebih seragam (lebih homogen) dibandingkan mahasiswa field independent. Selanjutnya, dengan lebih tingginya simpangan baku skor kemampuan komunikasi matematis mahasiswa kelas eksperimen dibandingkan kelas kontrol, menunjukkan bahwa kemampuan komunikasi matematis mahasiswa kelas eksperimen lebih bervariasi (lebih heterogen) dibandingkan kelas kontrol.

Berdasarkan skor rata-rata dan simpangan baku di atas, maka tampak bahwa secara numerik terdapat perbedaan kemampuan komunikasi matematis mahasiswa antar kelas dan antar gaya kognitif. Namun, belum tentu perbedaan ini bersifat signifikan secara statistik. Oleh karena itu, analisis data dilanjutkan dengan uji statitik inferensianl berupa uji normalitas, homogenitas, dan anova dua arah. Adapun rekapitulasi perhitungan uji statisti tersebut dapat dilihat pada tabel 11 berikut.

Tabel 11. Rekapitulasi Hasil Uji Statistik Inferensial

\begin{tabular}{|c|c|c|c|c|}
\hline & $\begin{array}{c}\text { Nilai } \\
\text { Signifikansi } \\
\end{array}$ & Bunyi Hipotesis & Kriteria & Kesimpulan \\
\hline $\begin{array}{c}\text { Uji } \\
\text { Normalitas }\end{array}$ & 0,082 & $\begin{array}{l}\mathrm{H}_{0} \text { : Data skor kemampuan komunikasi } \\
\text { matematis mahasiswa berdistribusi } \\
\text { normal } \\
\mathrm{H}_{0} \text { : Data skor kemampuan komunikasi } \\
\text { matematis mahasiswa tidak } \\
\text { berdistribusi normal }\end{array}$ & \multirow{2}{*}{$\begin{array}{c}\text { jika nilai } \\
\text { signifikansi } \\
\text { lebih dari } \\
\alpha=0,05, \\
\text { maka } \mathrm{H}_{0} \\
\text { diterima dan } \\
\mathrm{H}_{\mathrm{a}} \text { ditolak } \\
\text { (Trihendradi, } \\
\text { 2019) }\end{array}$} & Terima $\mathrm{H}_{0}$ \\
\hline $\begin{array}{c}\text { Uji } \\
\text { Homogenitas }\end{array}$ & 0,288 & $\begin{array}{l}\mathrm{H}_{0}: \text { Tidak terdapat perbedaan variansi } \\
\text { data skor kemampuan komunikasi } \\
\text { matematis mahasiswa } \\
\mathrm{H}_{1} \text { : Terdapat perbedaan variansi data } \\
\text { skor kemampuan komunikasi } \\
\text { matematis mahasiswa }\end{array}$ & & Terima $\mathrm{H}_{0}$ \\
\hline $\begin{array}{l}\text { Uji Anova } \\
\text { Dua Arah }\end{array}$ & 0,424 & $\begin{array}{l}\mathrm{H}_{0} \text { : Tidak terdapat perbedaan } \\
\text { kemampuan komunikasi matematis } \\
\text { antara mahasiswa yang belajar } \\
\text { menggunakan buku ajar program linier } \\
\text { terintegrasi keislaman dengan } \\
\text { mahasiswa yang belajar dengan } \\
\text { menggunakan pembelajaran } \\
\text { konvensional } \\
\mathrm{H}_{1} \text { : Terdapat perbedaan kemampuan } \\
\text { komunikasi matematis antara }\end{array}$ & $\begin{array}{c}\text { jika nilai } \\
\text { signifikansi } \\
\text { lebih dari } \\
\alpha=0,05, \\
\text { maka } \mathrm{H}_{0} \\
\text { ditolak dan } \\
\mathrm{H}_{\mathrm{a}} \text { diterima } \\
\text { (Trihendradi, } \\
\text { 2019) }\end{array}$ & $\mathrm{H}_{0}$ ditolak \\
\hline
\end{tabular}




\begin{tabular}{|c|c|c|c|}
\hline $\begin{array}{c}\text { Nilai } \\
\text { Signifikansi }\end{array}$ & Bunyi Hipotesis & Kriteria & Kesimpulan \\
\hline & $\begin{array}{l}\text { mahasiswa yang belajar menggunakan } \\
\text { buku ajar program linier terintegrasi } \\
\text { keislaman dengan mahasiswa yang } \\
\text { belajar dengan menggunakan } \\
\text { pembelajaran konvensional }\end{array}$ & & \\
\hline 0,533 & $\begin{array}{l}\mathrm{H}_{0} \text { : Tidak terdapat perbedaan } \\
\text { kemampuan komunikasi matematis } \\
\text { antara mahasiswa dengan gaya kognitif } \\
\text { field dependent dengan field independet } \\
\mathrm{H}_{1} \text { : Terdapat perbedaan kemampuan } \\
\text { komunikasi matematis antara } \\
\text { mahasiswa dengan gaya kognitif field } \\
\text { dependent dengan field independet }\end{array}$ & & $\mathrm{H}_{0}$ ditolak \\
\hline 0,227 & $\begin{array}{l}\mathrm{H}_{0} \text { : Tidak terdapat interaksi } \\
\text { penggunaan buku ajar program linier } \\
\text { terintegrasi keislaman dan gaya kognitif } \\
\text { terhadap kemampuan komunikasi } \\
\text { matematis mahasiswa } \\
\mathrm{H}_{1} \text { : Terdapat interaksi penggunaan } \\
\text { buku ajar program linier terintegrasi } \\
\text { keislaman dan gaya kognitif terhadap } \\
\text { kemampuan komunikasi matematis } \\
\text { mahasiswa }\end{array}$ & $\begin{array}{c}\text { jika nilai } \\
\text { signifikansi } \\
\text { lebih dari } \\
\alpha=0,05, \\
\text { maka } \mathrm{H}_{0} \\
\text { diterima dan } \\
\mathrm{H}_{\mathrm{a}} \text { ditolak } \\
\text { (Trihendradi, } \\
\text { 2019) }\end{array}$ & $\mathrm{H}_{0}$ diterima \\
\hline
\end{tabular}

Berdasarkan tabel 11, tampak bahwa data skor kemampuan komunikasi matematis mahasiswa berdistribusi normal dengan varians yang homogen. Oleh karena itu, data memenuhi syarat untuk dilakukan uji anova dua arah. Dengan menggunakan uji anova dua arah, diketahui walaup terdapat pengaruh faktor penggunaan buku ajar dan gaya kognitif secara masing-masing terhadap kemampuan komunikasi matematis mahasiswa, namun secara bersamaan tidak terdapat interaksi. Hal ini lebih detail dapat dilihat pada gambar berikut.

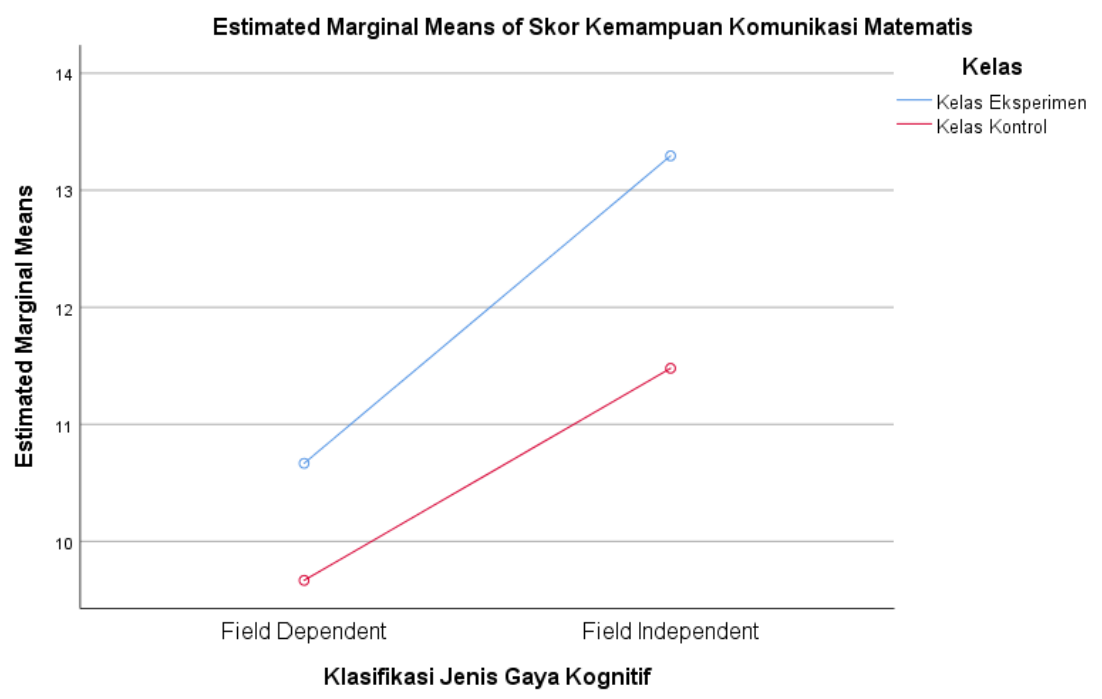

Gambar 4. Grafik Interaksi antara Penggunaan Buku Ajar dan Perbedaan Gaya Kognitif terhadap Kemampuan Komunikasi Matematis Mahasiswa 
Garis yang tidak berpotongan pada grafik di atas menunjukkan bahwa tidak terdapatnya interaksi antara penggunaan buku dengan perbedaan gaya kognitif mahasiswa (Trihendradi, 2019). Olahan dan analisis data hasil penelitian menunjukkan bahwa secara bersama-sama, faktor penggunaan buku ajar dan perbedaan gaya konitif tidak berpengaruh terhadap kemampuan komunikasi matematis mahasiswa (tidak terdapat interaksi). Peneliti berasumsi bahwa tidak adanya interaksi karena barangkali terdapat hubungan antara kedua variabel bebas (penggunaan buku ajar dan gaya kognitif) serta karena data kemampuan komunikasi matematis berdistribusi normal. Hal ini sebagaimana yang dikemukakan oleh R-Stats (2020), bahwa terdapat beberapa penyebab yang menyebabkan tidak terjadinya interkasi, yaitu: variabel terikat berskala interval atau rasio (data continous), tidak terdapat outlier (pencilan) pada variabel terikat, dua variabel bebas terdiri dari tiga atau lebih kelompok kategori, tidak ada hubungan antara observasi di setiap kelompok atau antar kelompok itu sendiri, variabel terikat terdistribusi secara normal, dan tidak ada hubungan antara kedua variabel bebas.

Namun, jika ditinjau masing-masingnya, penggunaan buku ajar program linier terintegrasi keislaman berpengaruh terhadap kemampuan komunikasi matematis mahasiswa. Pengaruh ini bersifat positif. Hal ini dilihat dari lebih tingginya rata-rata skor kemampuan komunikasi matematis mahasiswa kelas eksperimen dibandingkan kelas kontrol. Hal ini sejalan dengan hasil penelitian yang dilakukan oleh Sutrisno, Prasetyowati, \& Kartinah (2018) dan Gordah \& Astuti (2013) yang menyatakan bahwa penggunaan buku ajar berpengaruh terhadap kemampuan komunikasi matematis subjek yang diteliti. Hal ini sejalan dengan penelitian yang dilakukan oleh Wahyuni, Yati, \& Fadila (2020)

Selanjutnya, perbedaan gaya kognitif juga memberikan pengaruh terhadap kemampuan komunikasi matematis mahasiswa. Rata-rata skor kemampuan komunikasi matematis mahasiswa dengan gaya kognitif field independent lebih tinggi dibandingkan dengan mahasiswa field dependent. Hal ini menunjukkan bahwa kemampuan komunikasi matematis mahasiswa field independent lebih baik daripada field dependent, yang sejalan dengan apa yang disampaikan secara teoritis bahwa orangorang yang field independent lebih cenderung menekankan aktivitas pemecahan masalah dan bersifat analytical thinkers dibandingkan orang-orang yang field dependent (O’Brien dkk., 2001). Adanya pengaruh perbedaan gaya kognitif terhadap kemampuan komunikasi matematis ini sejalan dengan hasil penelitian yang dilakukan oleh Pratiwi (2015), Nurmalia, Yuhana, \& Fatah (2019), dan Achir, Usodo, \& Setiawan (2017).

Terkait respon positif yang termasuk pada kategori tinggi yang diberikan mahasiswa terhadap penggunaan buku ajar, hal ini sejalan dengan keaktifan mahasiswa dalam melakukan kegiatan diskusi lewat pengajuan pertanyaan terkait materi yang ada. Banyaknya komentar dan pertanyaan yang diberikan mahasiswa pada kelas google classroom menunjukkan bahwa mahasiswa memang aktif dalam penggunaan buku ajar ini.

\section{KESIMPULAN}

Kesimpulan pada penelitian ini terdiri atas tiga hal, yaitu: (1) Terdapat perbedaan kemampuan 
komunikasi matematis antara mahasiswa yang belajar menggunakan buku ajar program linier terintegrasi keislaman dengan mahasiswa yang belajar dengan menggunakan pembelajaran konvensional, (2) Terdapat perbedaan kemampuan komunikasi matematis antara mahasiswa dengan gaya kognitif field dependent dengan field independent, dan (3) Tidak terdapat interaksi antara penggunaan buku ajar program linier terintegrasi keislaman dan gaya kognitif terhadap kemampuan komunikasi matematis mahasiswa.

Terkait tidak terdapatnya interaksi, peneliti memberikan rekomendasi kepada peneliti selanjutnya untuk mengkaji dan membuktikan apakah dua variabel bebas yang memiliki hubungan secara signifikan dan data variabel terikatnya tidak berdistribusi normal akan sejalan dengan terjadinya interaksi antara kedua variabel bebas dan variabel terikatnya.

\section{REFERENSI}

Achir, Y. S., Usodo, B., \& Setiawan, R. (2017). Analisis Kemampuan Komunikasi Matematis Siswa dalam Pemecahan Masalah Matematika pada Materi Sistem Persamaan Linear Dua Variabel. Jurnal Penelitian Pendidikan, 20(1), 78-87.

Akbarizan. (2014). Integrasi Ilmu: Perbandingan antara UIN Suska Riau dan Universitas UMMU Al Quran Makkah. Pekanbaru: Suska Press.

Ariawan, R., \& Nufus, H. (2017). Profil Kemampuan Koneksi Matematis Mahasiswa dalam Menyelesaikan Masalah pada Mata Kuliah Kalkulus 1 ditinjau berdasarkan Gaya Kognitif. Suska Journal of Mathematics Education, 3(2), 102-110. https://doi.org/10.24014/sjme.v3i2.4036

Gordah, E. K., \& Astuti, R. (2013). Meningkatkan Kemampuan Komunikasi Matematis Mahasiswa Melalui Pengembangan Bahan Ajar Geometri Dasar Berbasis Model Reciprocal Teaching di STKIP PGRI Pontianak. Makalah disajikan pada Seminar Nasional Matematika dan Pendidikan Matematika, Universitas Negeri Yogyakarta, 9(2), 227-232.

Hendriana, H., Rohaeti, E., \& Sumarmo, U. (2017). Hard Skill and Soft Skill Matematik Siswa. Bandung: Refika Aditama.

Kurniati, A. (2015). Mengenalkan Matematika terintegrasi Islam kepada Anak Sejak Usia Dini. Suska Journal of Mathematics Education, 1(1), 1-8. https://doi.org/10.24014/sjme.v1i1.1326

Lestari, K. E., \& Yudhanegara, M. R. (2017). Penelitian Pendidikan Matematika. Bandung: Refika Aditama.

Nufus, H., \& Ariawan, R. (2017). Keterkaitan Hubungan antara Kemampuan Komunikasi dan Penalaran Matematis Siswa. Symmetry: Pasundan Journal of Research in Mathematics Learning and Education, 2(1), 29-42. https://doi.org/10.23969/symmetry.v2i1.240

Nufus, H., \& Nurdin, E. (2016). Program Linier. Pekanbaru: Cahaya Firdaus.

Nurmalia, I., Yuhana, Y., \& Fatah, A. (2019). Analisis Kemampuan Komunikasi Matematis Ddtinjau dari Gaya Kognitif pada Siswa SMK. Journal of Authentic Research on Mathematics Education (JARME), l(2), 105-111. 
Efektivitas Penggunaan Buku Ajar Program Linier Terintegrasi Keislaman terhadap Kemampuan Komunikasi Matematis

O’Brien, T. P., Butler, S. M., \& Bernold, L. E. (2001). Group Embedded Figures Test and Academic Achievement in Engineering Education. International Journal Engineering, 17(1), 89-92.

Pratiwi, D. D. (2015). Analisis Kemampuan Komunikasi Matematis dalam Pemecahan Masalah Matematika sesuai dengan Gaya Kognitif dan Gender. Al-Jabar: Jurnal Pendidikan Matematika, 6(2), 131-142.

Riduwan, \& Sunarto. (2013). Pengantar Statistika untuk Penelitian Pendidikan, Sosial, Ekonomi, Komunikasi, dan Bisnis. Bandung: Alfabeta.

R-Stats. (2020). Anova Dua Arah Tanpa Interaksi. Diambil 24 Desember 2021, dari Rumus Statistik website: https://www.rumusstatistik.com/2020/12/anova-dua-arah-tanpa-interaksi.html

Sumarmo, U. (2013). Berpikir dan Disposisi Matematik serta Pembelajarannya. Bandung: Universitas Pendidikan Indonesia.

Sutrisno, S., Prasetyowati, D., \& Kartinah, K. (2018). Efektivitas Buku Ajar Matematika SMP Berbasis 3-D untuk Meningkatkan Kemampuan Komunikasi Matematis Siswa. JURNAL SILOGISME: Kajian Ilmu Matematika dan Pembelajarannya, 3(1), 8-13.

Trihendradi, C. (2019). Step by Step IBM SPSS 21: Analisis Data Statistik. Yogyakarta: Penerbit Andi. Turmudi, T. (2006). Islam Sains \& Teknologi: Menggagas Bangunan Keilmuan Fakultas Sains dan Teknologi Islam Masa Depan. UIN-Maliki Press.

Ulya, H. (2015). Hubungan Gaya Kognitif dengan Kemampuan Pemecahan Masalah Matematika Siswa. Jurnal konseling GUSJIGANG, 1(2), 1-12.

Undang-Undang Republik Indonesia Nomor 12 Tahun 2012 tentang Pendidikan Tinggi. (2012). Diambil dari https://unnes.ac.id/wp-content/uploads/uu-12-2012.pdf.

Wahyudin. (2008). Pembelajaran dan Model-model Pembelajaran. Bandung: UPI Press.

Wahyuni, S., Yati, M., \& Fadila, A. (2020). Pengembangan Modul Matematika Berbasis REACT terhadap Kemampuan Komunikasi Matematis Peserta Didik. Jambura Journal of Mathematics Education, 1(1), 1-12.

Woolfolk, A. E. (1993). Educational Psychology 5 Edition. Singapore: Allyn and Bacon. 